\title{
Contrasting Nature, Gender, and Genre in Anne Finch's “A Nocturnal Reverie"
}

\section{Kairo Martens}

Although she wrote few nature poems, Anne Finch is often remembered as a nature poet because it was her poem "A Nocturnal Reverie," the bucolic final entry in her 1713 collection, Miscellany Poems, on Several Occasions. Written by a Lady, that first revived critical interest in her work in the early years of the Romantic movement. William Wordsworth famously praised Finch's "Reverie" in an essay prefacing his 1798 collection with Samuel Coleridge, Lyrical Ballads, for being one of the few worthwhile poems since John Milton's epic "Paradise Lost," and for demonstrating an exceptional amount of "genuine imagination" and "feeling" in its representation of a "new image of external Nature" (qtd. in McGovern 81). While there is evidence for Wordsworth's interpretation of "Reverie" as a proto-Romantic opus, the poem, like much of Finch's body of work, resists any singular reading because of its unique construction and nuanced themes. "Reverie" stands out not only because it straddles the line between the Neoclassical Augustan age and the later Romantic movement-somewhere between the two in terms of form and content-but also because it showcases Finch's ability to subtly subvert the traditional dichotomies of gender as well as humans versus nature.

In terms of form, "A Nocturnal Reverie" is rooted in two venerated, classically inspired traditions of poetry that both the Augustans and the Romantics admired-the first of which being, as its title suggests, the nocturne. The nocturne originates from John Milton's epic Paradise Lost as well as his contemplative "II Penseroso" (Miller 603; Quinsey 71), which together form the model for "rural poem[s] in praise of night" (Quinsey 64) such as "Reverie." In imitation of Milton's nocturnes, "Reverie" takes place from dusk 'til dawn outside of a village and is written as a single, continuous sentence which opens with and repeats the refrain "In such a night" (Finch, lines 1, 7, \& 47) to set a private, reflective tone. With all the people gone to bed, the poet credits the presence of "darkness and silence" and the absence of the "delusions and distractions of the day" (Quinsey 64) for the "Joys in th' inferior world, and thinks it like her own" (Finch, line 46). Where Milton's nocturnes are Edenic scenes in which higher powers bestow wisdom, Finch places "no authority in this poem-no goddess Melancholy or divine or masculine presence to whom she is praying" (Quinsey 76). Indeed, "heav'ns' mysterious face" is literally "veil[ed]" by the "passing clouds" (Finch, lines 7-8) and the poet is quite alone in her contemplation of the feminized landscape below the "waving moon... trembling leaves," and "softest shadow[s]" that surround her (lines 4, 23). Rather than the divine, it is real natural phenomena that inspire reflection and move "the free soul to a composedness charmed" (line 43) in "Reverie." Finch's nocturne is unlike Milton's in that it abandons expressly religious allegory in favor of imagery with a more grounded, secular flavor that prefigures the greater cultural shift towards humanistic rationalism popularized in the Age of Enlightenment and the latter years of the Augustan era of literature. In this way, Finch revisits the nocturne by imitating its form with a novel lens of "Lockean empiricism" that results in a re-gendered "Eden without Satan" (Quinsey 65) and demonstrates her unique, feminist point of view on the allegorical implications of the form.

Vol. 5(1) | DOI: https://doi.org/10.31542/muse.v5i1.1998 
The second model for "Reverie," the pastoral, is also revisited with this new perspective. With its focus on idealized natural landscapes and rural life, the pastoral genre was popularized by Finch's Augustan contemporaries such as Alexander Pope (Miller 2), who revived classical models like Virgil's eclogues for urban audiences who enjoyed the bucolic image of the country. The setting of "Reverie" is typical of contemporary Augustan pastoral depictions of country life, complete with "pastures" and "haycocks" (Finch, lines 27-28), but it is also dense with natural, realistic images that excited the later Romantics by appealing directly to the senses and the imagination, such as "Whilst now a paler hue the foxglove takes, / Yet chequers still with red the dusky brakes" (lines 15-16). However, "Reverie" is written in twenty-five heroic couplets like a contemporary Augustan pastoral poem, which, as McGovern points out in her critical biography of Finch, provide a sense of "the careful control and ... containment" and serve as a reminder that the poem makes "rational, moralistic reflections," not "ecstatic soarings of a free Romantic spirit" (82). Where "Reverie" differs most strikingly from its contemporaries is in the fact that it is not at all concerned with the cliché doe-eyed country swains, nor any other humans for that matter, since the poem is set in the middle of the night, "whilst tyrant-man does sleep" (Finch, line 38). With life "beneath the village walls" (line 35) quieted by the darkness, the poet enjoys the absence of the generic characters of pastoral poetry and the serenity of the night, musing: "In such a night let me abroad remain, / Till morning breaks, and all's confused again" (lines 4748). Just as easily as Finch conjures the imagery and setting of the pastoral form, she also questions its assumption of harmony between humans and nature by drawing attention to the short-lived nature of the "Nocturnal Reverie" through her wishes to avoid the boorish country folk and remain among the animals.

The nocturne and the pastoral form the generic base upon which "Reverie" is built, but Finch takes each in a new direction by subverting traditional dichotomies. Like Milton's nocturnes, "Reverie" subverts the expectation that daylight should be associated with "knowledge, reason, clear judgment, and order" and "night with darkness, error, confusion, loss of distinction, and delusive fancy" (Quinsey 71), but, unlike Milton, Finch is not interested in "unveiling hidden depths or the secret truth" (Smith 261), but rather in examining the causes and effects of real natural phenomena. It is for this reason that Wordsworth and his contemporaries recognized a Romantic sentiment in "Reverie;" Finch shows that nature's beauty can calm a soul weary from pursuing "pleasures, seldom reached" (Finch, line 50) during the drudgery of daily life, and, as a result, emphasizes the dichotomy between "the social world and the natural world" (McGovern 80). Likewise, Finch's descriptions of nature also feature purposefully gendered language in such a way that "recall[s] female experience and longstanding gendered oppositions" (Quinsey 71). Finch subverts not only the traditional forms of the nocturne and the pastoral therein, but also questions the two major thematic contrasts that these genres are situated upon: humans versus nature and male versus female.

The conventional harmonious relationship between humans and nature from pastoral poetry is cast away in "Reverie"-criticized, even-because of the conflict and contrast shown between the two. It is, in fact, the absence of rude human activity that is prerequisite for the poet to observe the rare, unappreciated beauties that "no fierce light disturb[s]" (Finch, line 40) at night, such as "odours, which declined repelling day, / Through temp'rate air uninterrupted stray" (lines 21-22). The poet describes the shaded natural images with an affectionate tone and "sensory immediacy" (Quinsey 66)—such as "darkened groves," "falling waters," and "sunburnt 


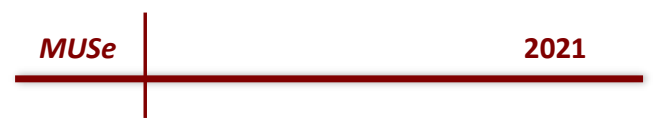

hills" (Finch, lines 23-27) -that further proves that nature itself, not the bucolic lifestyle, to be the object of the poem's admiration. The animals and the plants are especially beautiful under the quiet moonlight, as opposed to the frightful, man-made structures: "ancient fabric [building], awful in repose" or the "swelling haycocks [that] thicken up the vale" (lines 26-7). In the final lines, we are reminded once more that the now-peaceful atmosphere with all "the elements of rage disarmed" (line 44) is fated to come quickly to an end as the dawn arrives-a direct inversion of "the closural sunset in Virgilian eclogue" (Miller 14) wherein the rising sun renews tranquility and happiness. The theme of harmony between human and nature is disrupted by Finch's emphasis that the nightly absence of humankind is a temporary blessing in the countryside. Interestingly, Finch carries this objection even further in the other poems in Miscellany Poems, such as in "By neer resemblance that Bird betray'd," which similarly excoriates the idea that humankind's treatment of the natural world does not stifle it:

O man what inspiration was thy Guide

Who taught thee Light and Air thus to divide

To lett in all the usefull beames of Day

Yett force as subtil winds without thy Sash to stay (lines 16-19).

Unlike the "man" in "Bird betray'd" who tries to "force" and "divide" nature, it is only by passively observing the serenity of night in "Reverie" that the poet is moved to these "silent musings" which "urge the mind to seek / Something, too high for syllables to speak" (lines 41-42). Finch's tone towards humans and nature in her poetry expresses her view that the beauty and interconnectedness of nature cannot really be appreciated in the masculinized daytime as is assumed by the pastoral and the nocturne. Instead, Finch cultivates the idea that it takes more gentle, feminine wisdom to see through "the gloom" (line 25) and be moved to a spiritual "composedness" (line 43).

The other major method by which Finch accomplishes this is by using gendered language to anthropomorphize animals and natural phenomena throughout "Reverie." For example:

And only gentle Zephyr fans his wings,

And lonely Philomel, still waking, sings;

Or from some tree, famed for the owl's delight,

She, hollowing clear, directs the wand'rer right (lines 3-6).

The feminine Philomel, or nightingale, is the one to guide the lost wanderer to her destination whereas the masculine Zephyr is "gentle" and quiet, suggesting a feminine power to the nocturnal setting that revises the theme of feminine weakness and temptation in the nocturnal scene between Eve and Satan in Milton's "Paradise Lost." Finch also praises a female friend, Anne Tufton, Countess of Salisbury, for standing "the test of every light, / In perfect charms, and perfect virtue bright" (lines 19-20) in the twilight the dusk brings, comparing her to the "scattered glow-worms" who "Show trivial beauties watch their hour to shine" (lines 17-18). By using gendered language and comparing the animals of the countryside to women, Finch again draws attention to their contrast with the aforementioned "tyrant-man" who is absent from the scene. Instead of the pastoral trope of young lovers or shepherds guarding their flocks, "Reverie" places the "unmolested kine," "loosed horse" (lines 29, 34) in the spotlight along with the feminized glow worms and Philomel. Moreover, these animal's descriptions as "unmolested" and "loosed" suggest that they have been emancipated by the nighttime, and the poet imagines 
that the nighttime has come to free the animals from their "cares... toils... [and] clamours" (line 49) that troubled them in the daytime, and that they enjoy a "shortlived jubilee" (line 37) with humans gone. The "jubilee" is a reference to the Old Testament, in which one "jubilee year" would be given to Israel every fifty years wherein the "slaves were to be freed and fields left unploughed to ensure physical, social, and spiritual renewal" (Quinsey 74). Alongside the themes of spiritual renewal and feminine pronouns used for the animals, Finch uses the jubilee allusion to lament the daytime confinement of women who, like the animals in "Reverie," can only find peace while the oppressive actions of the masculine powers that dominate the daytime are put away. As in Finch's "The Introduction," which mockingly bemoans the audacity of women to complain about their exclusion from the public sphere: "Alas! a woman that attempts the pen, / Such an intruder on the rights of men, / Such a presumptuous creature" (lines 9-11), "Reverie" further amplifies Finch's sardonic tone towards sexism by making playful, melodramatic comparisons between the treatment of women and the treatment of animals.

Finch's synthesis of the symbolism of animals freed in the night, the suggestion that countryside's true beauty is revealed by the absence of people and daylight, and the underlying expression of her feminist concerns demonstrates her ability to deftly blend "nature and culture, the literal and the figurative, the general and the particular" (Smith 259). As Dr. Katherine Quinsey puts it, part of the enduring appeal of "Reverie" is that "it spans so smoothly the trajectory from the Cavalier [read: Neoclassical] to the Romantic tradition" (64). By revisiting classical models and Milton, Finch expresses her skepticism towards the unrealistic, idyllic presentation of humankind's relationship with nature and the presumed 'natural' confinement of women to the domestic sphere in daily life. In these ways, "Reverie" epitomizes the distinctive subversive streak in Finch's poetry that distinguishes her work as unique and visionary. 


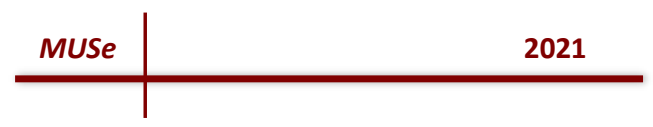

\section{References}

Black, Joseph et al., editors. The Broadview Anthology of British Literature Volume 3: The Restoration and the Eighteenth Century, Broadview Press, 2006.

Finch, Anne. "A Nocturnal Reverie." The Broadview Anthology of British Literature Volume 3: The Restoration and the Eighteenth Century, edited by Joseph Black et al., Broadview Press, 2006, p. 289.

---. "By neer resemblance that Bird betray'd." The Broadview Anthology of British Literature Volume 3: The Restoration and the Eighteenth Century, edited by Joseph Black et al., Broadview Press, 2006, pp. 288-9.

---. "The Introduction." The Broadview Anthology of British Literature Volume 3: The Restoration and the Eighteenth Century, edited by Joseph Black et al., Broadview Press, 2006, pp. 285-6.

McGovern, Barbara. Anne Finch and Her Poetry: A Critical Biography. University of Georgia Press, 1992.

Miller, Christopher R. "Staying out Late: Anne Finch's Poetics of Evening." Studies in English Literature, 1500-1900, vol. 45, no. 3, 2005, pp. 603-23.

Quinsey, Katherine M. "Nature, Gender, and Genre in Anne Finch's Poetry: 'A Nocturnal Reverie." Imitation et Invention Au Siècle Des Lumières/Imitation and Invention in the Eighteenth Century, edited by Marc André Bernier and Suzanne Foisy, American Academic Press, 2007, pp. 63-77.

Smith, Courtney Weiss. "Anne Finch's Descriptive Turn.” Eighteenth Century: Theory \& Interpretation, vol. 57, no. 2. University of Pennsylvania Press, 2016, pp. 251-265. 